\title{
THE ROLE OF SELECTED ENVIRONMENTAL FACTORS AND THE TYPE OF WORK PERFORMED ON THE DEVELOPMENT OF UROLITHIASIS - A REVIEW PAPER
}

\section{GRZEGORZ WRÓBEL and TADEUSZ KUDER}

\author{
Jan Kochanowski University in Kielce, Kielce, Poland \\ Institute of Medical Sciences, Faculty of Medicine and Health Sciences, Department of Anatomy
}

\begin{abstract}
Urolithiasis is a disease of the genitourinary system, which is defined as the presence of urinary stones at any place in the urinary tract, resulting from the precipitation reaction of chemical compounds. The aim of this study is to demonstrate the important role of selected environmental factors (climate, ambient temperature) and the type of profession performed in the development of urolithiasis. In this field, the literature including original and review papers related to the epidemiology, pathogenesis and risk factors of urolithiasis was analyzed. The study used electronic databases such as Medline, Web of Science and Google Scholar. The prevalence of urolithiasis has increased in recent decades in both developed and developing countries. It is believed that this growing trend is associated with lifestyle changes such as the lack of physical activity, poor eating habits and global warming. Many factors are responsible for the formation of urinary stones. In literature, there is a division into individual and environmental factors. Today, external factors in the form of climate changes (global warming), geographical conditions and seasonal fluctuations, and the type of profession performed are becoming more and more important in the context of the occurrence of urinary stones. Currently, the presence of urolithiasis is becoming a significant problem all over the world and searching for causes is not easy, but particular attention should be paid to certain predispositions resulting from environmental factors, such as ambient temperature and the type of work performed. Int J Occup Med Environ Health. 2019;32(6):761-75
\end{abstract}

Key words:

urolithiasis, nephrolithiasis, kidney stone, epidemiology, pathogenesis, risk factors

\section{INTRODUCTION}

Urolithiasis is a disease of the genitourinary system, which is defined as the presence of urinary stones at any place in the urinary tract [1]. Urolithiasis is one of the oldest diseases known to mankind, as evidenced by archaeological research, with one of the first of many studies conducted by English archaeologist E. Smith in 1901, which proved the presence of stones in the Egyptian mummies of El Amrah (estimated 4500-5000 BC). Physicians of the early Middle Ages widely noticed the problem of urolithiasis, which was associated with characteristic clinical symptoms. That is why the first information on the possible treatment for these ailments was the "excision of stones" from patients dying of pain. Over the centuries, urolithiasis affected such personalities as Michelangelo, Ignatius of Loyola, Louis XIV or Napoleon Bonaparte [2].

In general, the disease refers to the formation of deposits in the urinary system (stones) that result from the pre-

Funding: this work was supported by the Minister of Science and Higher Education (project No. 024/RID/2018/19 entitled "Regional Initiative of Excellence in 2019-2022"). Received: May 17, 2019. Accepted: August 9, 2019.

Corresponding author: Grzegorz Wróbel, Jan Kochanowski University in Kielce, Institute of Medical Sciences, Faculty of Medicine and Health Sciences, Department of Anatomy, IX Wieków Kielc 19, 25-317 Kielce, Poland (e-mail: grzegorz.wrobel@ujk.edu.pl). 
cipitation reaction of the chemical compounds which are components of urine. The classification of urinary stones depends on such criteria as the size of the deposit, its location in the urinary tract, chemical composition, formation etiology, X-ray properties, and the risk of secondary formation [3,4]. In terms of morphological parameters, the size of the stones is usually given in 1 or 2 dimensions, and the measurement scale used corresponds to the largest diameter: < 5 mm, 5-10 mm, 10-20 mm, and > $20 \mathrm{~mm}$. In terms of location, stones can be classified according to their anatomical position: the upper, middle and lower calyx; the renal pelvis; the upper, middle and distal segment of the ureter; or the urinary bladder. This is why there are several types of urolithiasis: renal, ureteral, bladder-type and multifocal.

In a study by Lallas et al. [5], it was shown that urinary stones are most frequently $(\sim 70 \%)$ found in the renal calyx system as compared to other locations within the urinary tract. Moreover, there was a correlation between the occurrence of deposits and the symptoms of microhematuria. In other research, Durgawale et al. [6] showed that urinary stones are more commonly located in the ureters than in the kidney itself. Due to the chemical composition of the deposits, depending on the substance constituting their main component, there are several types of nephrolithiasis: calcium (calcium-oxalate, calcium-phosphate), uric acid, and cystic stones [7].

The most common cases of diagnosed uric acid stones are deposits where calcium compounds are predominant in the chemical structure $(71 \%)$. Therefore, it appears striking that the majority of people who have been diagnosed with urinary system stones also have hypercalciuria, i.e., increased urinary calcium excretion. Increased intestinal calcium absorption, reduced reabsorption of calcium in renal tubules and excessive bone calcium release are mentioned as the causes of a disturbed calcium-phosphate balance. The role of food and nutrition in this regard is very important, because excessive calcium in the diet and an overdose of vitamin $\mathrm{D}_{3}$ stimulate the occurrence of hypercalciuria, for which dietary and pharmacological treatment is necessary [8,9]. In a study by Wróbel et al. [10] regarding the chemical structure of kidney stones in Poland, it was found that the most common chemical substance forming stones is calcium oxalate monohydrate $\left(\mathrm{CaC}_{2} \mathrm{O}_{4}{ }^{*} \mathrm{H}_{2} \mathrm{O}-84 \%\right)$, followed by hydroxyapatite $\left(\mathrm{Ca}_{10}\left(\mathrm{PO}_{4}\right) * 6(\mathrm{OH})_{2}-8 \%\right)$, and then struvite or magnesium-ammonium phosphate $\left(\mathrm{MgNH}_{4} \mathrm{PO}_{4} * 6 \mathrm{H}_{2} \mathrm{O}-6 \%\right)$, while the rarest are stones based on uric acid $\left(\mathrm{C}_{5} \mathrm{H}_{4} \mathrm{~N}_{4} \mathrm{O}_{3}-2 \%\right)$.

Many factors are responsible for the formation of urinary stones. In literature, there is a division into individual and environmental factors [11-14]. Individual factors include non-modifiable factors such as genetic determinants (mutations in the SLC3A1, SLC7A9, SLC22A12 and SLC2A9 genes or other adjacent ones) [15-17], ethnic origin, age, gender and lifestyle factors, i.e., eating habits, body mass index (BMI), dehydration, overweight, obesity, diabetes, hypertension, etc. It should also be noted that the presence of urinary stones may be associated with the occurrence of other diseases [18]. According to recent reports, a correlation between cancer and urolithiasis has been confirmed [19]. Environmental factors include ambient temperature, seasonal variability, the number of hours of sunshine, air humidity, atmospheric pressure, and precipitation. Included in this group are also environmental factors in socio-economic terms, such as the type of job (occupation), industrialization, education, or health care access [11-14,20,21].

Although there are numerous studies on urolithiasis, the knowledge is scattered in a range of articles that show various aspects of the problem, but there is no holistic approach. Therefore, an attempt has been made to organize this knowledge systematically and to discuss it.

The aim of this study is to demonstrate the important role of selected environmental factors (climate, ambient temperature) and the type of work performed in the development of urolithiasis. 


\section{METHODS}

The study included an analysis of literature data derived from original and review papers related to epidemiology, pathogenesis, and risk factors for urolithiasis. The study used electronic databases, such as Medline, Web of Science and Google Scholar. For the analysis, articles relevant to the study were searched for using the following keywords: urolithiasis, nephrolithiasis, kidney stone, epidemiology, pathogenesis, risk factors, and prevalence. Articles that did not show, whether directly or indirectly, the dependence of selected environmental factors (climate, ambient temperature) and the type of work performed in the development of urolithiasis were excluded from the study. The analysis was based on publications presenting the latest information on urolithiasis, as well as older articles that allowed to systematize knowledge in chronological order (1945-2019). Five hundred and seventy-six publications were collected, of which 452 did not meet the study criteria or were duplicated. One hundred and twenty-four publications fulfilling the above-mentioned criteria were eventually included in the study. Over $81 \%$ of the publications were published after 2000 , while $>50 \%$ of the articles were published in the last decade. Publications were available both in the Polish and English language.

\section{RESULTS}

\section{Epidemiology of urolithiasis}

As noted above, urolithiasis belongs to a group of the most common diseases of the genitourinary system. According to literature, the global incidence of urolithiasis ranges $1-20 \%$ [7,22-24]. It is most frequently observed in populations with a large proportion of meat in diets, but rarely in vegetarian and vegan populations. Regarding the geographical distribution, there is a higher occurrence of the disease in Western countries, e.g., Canada (12\%) and the United States (13-15\%); in European countries, the range is slightly lower (5-9\%), whereas it rarely occurs in East Asian countries, e.g., Japan (1-5\%). The highest morbidity risk affects the region of the Middle East, where it can range $20-25 \%$, due to climate conditions which lead to long-term exposure to the sun, an increased vitamin $\mathrm{D}_{3}$ production, and an increased daily fluid loss through the skin [25].

Choi et al. [26] showed that various climate factors in urban and rural areas might have an impact on the prevalence of urolithiasis and, therefore, the conditions associated with geographical location as well as the peculiarities of the population settlement (urban-rural) are integrated into the analysis of the prevalence of urolithiasis. According to numerous reports, the differences between urban and rural areas in correlation to urolithiasis are as follows: Pinduli et al. [27] showed the prevalence of urolithiasis for Buenos Aires at the level of $4 \%$ (for men $4.35 \%$ and for women 3.6\%), while Stamatiou et al. [28] in their studies showed a significant percentage of the population with urolithiasis in rural areas (15.2\%), whereby this was $17.5 \%$ for men and $13.2 \%$ for women.

Wang et al. [29] did not observe any significant differences in the prevalence of urolithiasis between urban and rural populations. As shown by the results of the 2010 study by Sas et al. [30], conducted in the USA, there were no differences in the incidence of nephrolithiasis in children from urban and rural areas, but these results cannot be directly compared to the adult population. Regarding the prevalence of urinary deposits among infants and children, it should be noted that they are rare and most often associated with urinary tract infections, urinary tract disorders or metabolic disorders (hypercalciuria and hypocitraturia) [11,31]. Sepahi et al. [32], in their studies conducted on 100 children under the age of 14 years, in whom urinary deposits were present, showed that in 54 subjects, bacterial infection was the main cause of urolithiasis. Despite the relatively incidental cases of urolithiasis in children, disturbing trends in the prevalence of this disease are observed nowadays [31,33-35]. In the 2012 study by Dwyer et al. [36], conducted in the 
north-central USA (Minnesota), a retrospective analysis of the prevalence of urolithiasis was performed, revealing that among children $<18$, the prevalence increased from 13/100 000 (1984-1990) to 36/100 000 personyears (2003-2008). In another state in the south-east of the USA (South Carolina), there was also an increasing incidence of urinary stones in children in 1996-2007 (from 7.9/100 000 in 1996 to 18.5/100 000 children in 2007); usually this problem concerned girls rather than boys, while the cause was indicated by adverse changes in eating habits [30,34,35,37]. According to a recent study by Modi et al. [38], the number of hospitalizations due to upper urinary tract urolithiasis in U.S. children significantly decreased in 2001-2014, while the percentage of hospitalized patients undergoing urolithiasis surgery significantly increased in the same period.

In Poland, among the few epidemiological data on urolithiasis in children, a significant increase in its prevalence in recent years has also been indicated [39]. According to Bochniewska et al. [39], currently children with urolithiasis account for $10 \%$ of all children hospitalized in Poland, in comparison to $2 \%$ in previous studies. In studies conducted by Kiliś-Pstrusińska et al. [40], it was shown that children $>4$ years of age accounted for $16 \%$ of all patients treated for urolithiasis in 1995-1999 at the Pediatric Nephrology Clinic in Wrocław. According to Gołąbek et al. [41], infants and children < 2 years of age accounted for $49 \%$ of all patients with uric acid stones. However, Kamińska and Bieroza [42] noted that the lack of sufficient epidemiological data made it difficult to assess the scale of this phenomenon among the pediatric population in Poland.

According to Alelign and Petros [43], the prevalence of urolithiasis has increased in recent decades in both developed and developing countries. It is believed that this growing trend is associated with lifestyle changes such as the lack of physical activity, poor eating habits and global warming $[20,44,45]$. In Europe, and more precisely in Ger- man studies conducted in 1979-2000, it was shown that among people aged $>14$ years, the number of new patients increased from 120 to 720/100 000 population, while the total number of patients increased from $4.0 \%$ to $4.7 \%$ of the population [46]. In other studies conducted in England in 2003-2014, a significant increase in the incidence of urolithiasis, of $33.7 \%$ over 12 years, was found. The results significantly demonstrated the scale of the health problem of urolithiasis in that country [47]. American studies also showed a significant increase in the incidence of kidney stones from 3.8\% (1976-1980) to 8.8\% (20072010) [48]. In East Asian countries, there is also a growing trend in the prevalence of this disease. Yu Liu et al. [20] reported that the incidence of urolithiasis had increased significantly over the last few decades in most Asian countries, including China (from $4 \%$ to 6.4\%), Japan (from $4.3 \%$ to $9.0 \%$ ), South Korea (from $3.5 \%$ to $11.5 \%$ ), Thailand (from $1.4 \%$ to $16.9 \%$ ), Saudi Arabia (from 6.8\% to $19.1 \%$ ), Iran (from $5.7 \%$ to $8.1 \%$ ) and Israel (from $1.2 \%$ to $9.2 \%$ ). It is worth noting that East Asian countries such as China, Japan or South Korea, due to their traditions and culinary habits, were less likely to have urolithiasis, which is why with the increase in the proportion of high-fat and high-sugar diets in many Asian countries, especially in China, the prevalence of this disease has also increased [20].

As regards the conditions that may affect the prevalence of this disease, sex, race, socio-economic status, eating habits and genetic factors are worth noting. According to literature data, urolithiasis appears in approx. $10-12 \%$ of men, while women show approx. $5 \%$ morbidity due to this disease; however, it should be noted that in the highly developed countries, the prevalence of the disease in obese women is increasing. Age $>60$ years reduces these statistics. In this period of life, the incidence of urolithiasis in women and men remains at a similar level. Other epidemiological data indicate a connection between belonging to a particular race and the incidence of uroli- 
thiasis. According to data, in Caucasian populations the incidence of the disease is 4 times higher than in Black and Asian populations. Regarding other conditions that could favor the prevalence of urolithiasis, a clear relationship was observed between the socio-economic status of the population and the location of urolithiasis, and the type of urinary stones, and more precisely their chemical structure [49-51].

Unfortunately, there are insufficient data on the incidence of urolithiasis in Poland. The lack of epidemiological analyses of this type of a disease in this country underscores the need for research in this area. According to the few data available, i.e., Roslana [52], and Kretowicz and Manitius [53], it can be assumed that in Poland urolithiasis affects approximately $2 \%$ of the population. However, considering the dietary habits of Poles, as well as the persistent increase in the incidence of urolithiasis in Europe [54], this low percentage appears rather dubious. Regarding the epidemiological data, it can be concluded that a higher incidence of urolithiasis affects industrialized countries, which are characterized by a high standard of living, which in particular applies to the most affluent groups [53].

\section{Pathogenesis of urolithiasis}

Due to the physicochemical aspects of the crystallization process in the human urinary tract, and errors occurring in biochemical processes in the body, the knowledge of the pathophysiology of urolithiasis remains inadequate, because there are many factors responsible for the formation of deposits in the urinary tract. According to Worcester and Coe [55], physiochemical and metabolic factors should be specified in the pathogenesis of urolithiasis. In the case of the former, the primary factor is the process of supersaturation - the saturation of urine with the substances present in it, while in the latter the main role is played by irregularities in the metabolism involving calcium-phosphate, purine and amino acid regulation, and errors occurring in the oxalic acid metabolism.

When seeking to answer the question regarding the causes or mechanisms explaining urinary stones formation, a few key scientific hypotheses should be mentioned. Stąpor [56] distinguished several theories, i.e., the theory of Lichtwitz protective colloids, with the urine crystals formation resulting from a disturbed balance between protective colloids and crystalloids in the solution. In Heller's crystallization theory, deposits are formed as a result of solution supersaturation and crystals cementing (grouting) with basic organic substances, which is the "scaffolding” for urinary stones. In Koch and Boshamer's theory, kidney function damage is indicated as the primary cause of stone formation, which results in impaired renal blood supply and determines the formation of spherical proteins with the adhesive ability of mineral salts. According to Carr's theory, deposits are formed by urine reflux between the renal pelvis, renal calyx and lymphatic vessels, which may result in chronic inflammation. In Randall's theory, toxic factors (bacterial toxins) in the interstitial tissue of the renal papilla, platelet calcifications called "Randall's plaque" are formed which, as their dimensions increase, lead to epithelium damage and penetrate into the urine. In Boyce and Dulce's theory, organic compounds, i.e., uroproteins and uromucoids (Tamm-Horsfall protein) appear in the urine, which are responsible for the formation of deposits, as they are the major component of urinary casts and kidney stones.

Today, there is no consensus as to whether Tamm-Horsfall protein is an inhibitor or promoter of crystal aggregation. However, according to Basavaraja et al. [57], most authors believe that this protein inhibits the aggregation of calcium oxalate monohydrates in alkaline $\mathrm{pH}$, solutions with low ionic strength and low divalent ion concentrations. Under changing conditions such as low $\mathrm{pH}$, high calcium, sodium and hydrogen ion concentration, as well as low protein concentration, it can promote aggregation. According to 
Bird and Khan [58], each of the theories has enriched the knowledge of urolithiasis. The formation of deposits in the human urinary tract is a complex multistage process with a multifactor basis.

By adopting a simplified mechanism, deposit formation in the urinary system corresponds with the supersaturation of crystallization-capable substances and the deficiency or impairment of crystallization-inhibiting substances or lithogenesis inhibitors. In the classic approach, primary urine is a solution saturated with various mineral salts, which undergo precipitation, which results in the formation of crystallization nuclei that, under normal conditions, are excreted during urination. The key role at this stage is played by urine lithogenesis inhibitors, which simultaneously prevent the enlargement of the already formed crystallization nuclei, as well as their aggregation, which aims to prevent the formation of larger molecules. In addition, crystallization inhibitors support the excretion of these crystals by preventing their adhesion to the renal tubules and urinary tract epithelium. The factors inhibiting crystallization are rapid urine flow, chemical compounds, i.e., magnesium, citrates, pyrophosphates, uromodulin (Tamm-Horsfall protein), nephrocalcin, osteopontin, glycosaminoglycans, urinary prothrombin fragment 1 , inter- $\alpha$ inhibitor, lithostatin, bikunin and calgranulin, while the factors promoting the crystallization process are low urine volume, increased excretion (uric acid, calcium, oxalates, phosphates), Tamm-Horsfall protein, low or high urine $\mathrm{pH}$, urinary tract infection, urinary stasis, and nanobacteria [57-59].

Urinary congenital disorders and genetic defects which lead to urinary stasis (e.g., pelvic-ureteral junction stenosis, horseshoe kidney or polycystic kidney disease) may accelerate or increase stone formation. In clinical terms, people post-nephrectomy are at high risk because due to having only 1 active kidney, ureter stenosis during deposit excretion may lead to acute kidney injury [55-60].

\section{The role of climate}

Today, external factors in the form of climate changes (global warming), geographical conditions and seasonal fluctuations (higher rates in summer than in winter) are becoming more and more important in the context of the occurrence of urinary stones. As indicated by a wealth of literature data [61-71], global climate change is an environmental factor that can significantly affect the incidence of urinary stones, which is clearly associated with changes in ambient temperature and exposure to sunlight. In general, a higher incidence of urolithiasis in warmer regions results from large water losses due to sweating and inadequate water supplementation; this condition determines low urine volume and is a risk factor in urolithiasis.

There is a documented relationship between the presence of urolithiasis due to geographical conditions. One of the first studies confirming this dependence in the USA was the research by Boyce et al. [72], which showed that the incidence of kidney stones was the highest in the southern states of South Carolina and Georgia, and the lowest in Wyoming and Missouri. Subsequent studies, including that by Tasian et al. [73] conducted on 60433 patients in 2005-2011, in several American cities - Atlanta, Georgia; Chicago, Illinois; Dallas, Texas; Los Angeles, California, Philadelphia, and Pennsylvania, have confirmed the adverse effects of high temperatures on kidney stones. According to the analysis of literature in general, in the USA there was a positive correlation between the occurrence of urolithiasis and the indicator of temperature and sunlight, with the increase in the occurrence of kidney stones being more noticeable in the hottest and sunniest parts of the country than in the coldest and least sunny $[63,64]$.

Similar relations were noted in other countries, i.e., in Iran [74], Saudi Arabia [75], and South Korea [76]. In Taiwan, there are regional differences in the incidence of urolithiasis, but they are not as statistically significant [77] as in Turkey, where a higher incidence of kidney stones was observed in the hottest geographic areas (the south and 
south-east), but this also lacked statistical evidence [78]. In Europe, using the example of Great Britain, there was a tendency for the incidence of kidney stones to increase in the southern (warmer) regions of England [79]; in other studies by Power et al. [80], this correlation was justified by the higher socio-economic status among patients in the south, who more often used health care.

Many studies have shown a relationship between hotter seasons or months and the occurrence of urolithiasis [64$67,69,70,81-83]$. On this basis, it can be assumed that the incidence of kidney stones varies, depending on the season of the year, which is determined by the warmer months of spring and summer. Basiri et al. [84], in their studies conducted in Iran, observed the highest number of cases in the months of June, July and November. Alkhunaizi [75], in his studies covering the years 1999-2010 in Saudi Arabia, showed a significantly higher incidence of kidney stones in patients in the hot season (May-September) than during the moderate season (October-April) (Figure 1). In Israel, in studies conducted by Sagy et al. [85] covering the years 2004-2015, the relationship between the frequency of reported health problems caused by the presence of stones in the urinary tract and the summer period covering June-September (with the mean air temperature of $25.5^{\circ} \mathrm{C}$ ) was shown. This relationship was also observed in regard to average temperature changes during the day. Additionally in this study, the relationship was shown for seasonal air humidity, the highest average value of which was in summer (68\%) in comparison with other seasons.

As already mentioned in the previous section, people with kidney stones have a tendency to excrete calcium with urine, which is associated with an excess of vitamin $\mathrm{D}_{3}$ [86]. Barger-Lux and Heaney [87] showed that the serum vitamin $\mathrm{D}_{3}$ levels generally fell in winter months compared to summer months, due to reduced exposure to sunlight. A completely different statement was presented by Attalla et al. [88], who showed that despite irrelevant differences in the serum vitamin $\mathrm{D}_{3}$ level, urinary calcium excretion was significantly

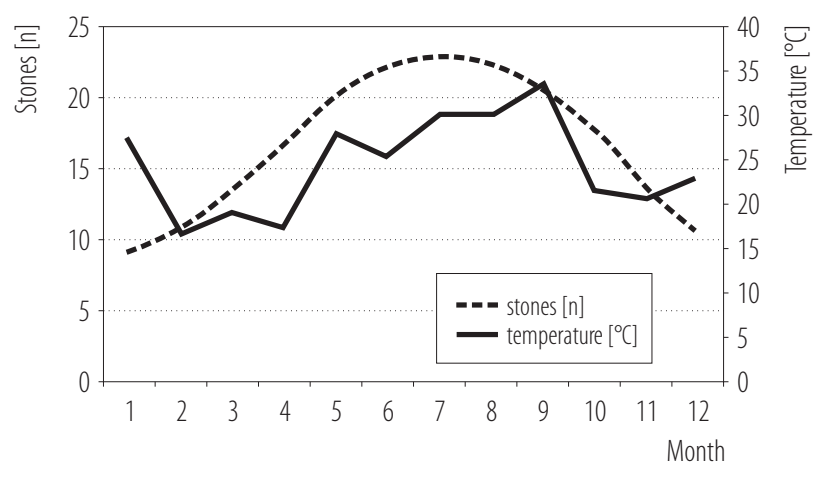

Figure 1. Monthly number of urinary stones in relation to the average monthly temperature from 1999 to 2010 [75]

higher in winter months compared to summer months, citing the co-occurrence of the other factors causing the formation of urinary stones, i.e., BMI which is associated with an increase in the calcium level in the urine [89-91], the supersaturation of uric acid in the urine [92] and calcium-oxalate stone formation [93], which inversely correlate with the serum vitamin $\mathrm{D}_{3}$ levels $[94,95]$. Laerum and Aarseth [96], in European research conducted in a partially industrialized rural area in eastern Norway, which is characterized by cold winters and mild summers, showed the occurrence of renal colic more often in winter months than in summer months. This may be due to internal temperatures, because the inhabitants of this region may tend to stay more frequently indoors than outdoors, due to the low temperatures outside in winter, while the reduced intake of fluids and eating habits during the winter come down to consuming products that belong to the group of risk factors for this disease.

Some studies have confirmed differences between the exposure time to an environmental factor, such as temperature, and a clinical manifestation, i.e., the occurrence of symptoms characteristic of urolithiasis. In studies by Evans and Costabile [97], an attempt was made to determine the time of formation of symptomatic urinary stones among originally healthy people who found themselves in southwestern Asia, which is a high-risk area for urolithiasis. They 
were compared in the period of March-August 2003, the time from the arrival of American soldiers in Kuwait and the time of the onset of acute renal colic in 1 military hospital located in this area. As a result of the study, it was noted that the average time for the development of symptomatic urinary stones was 93 days. In other studies conducted in France in 2002-2004, Doumerc et al. [98] recorded time delays of 2 months between exposure to higher temperatures and a clinical manifestation of symptoms.

\section{Occupational factors}

The type of profession, or rather the work environment, is an important factor affecting the formation of urolithiasis. In 1945, Pierce et al. [99] conducted the first studies on high temperature exposure in the work environment as a potential factor for the formation of urolithiasis. Other studies have shown that the incidence of urolithiasis in American soldiers in desert areas was twice as high as in mountain areas [100]. Later, numerous observations indicated that a higher incidence of stones applied to people working in conditions of high ambient temperature $[43,45-48,50,101,102]$. Borghi et al. [103], in their studies conducted at a glassworks facility, compared the incidence of kidney stones between operators working in a hot environment and sweating, and those working as controllers at a mild temperature. This study confirmed a higher incidence of urinary stones among machine operators than among people working in normal conditions ( $8.4 \%$ compared to $2.4 \%$ in the control group); chronic dehydration was indicated as the reason. In other studies, concerning people working in the steel industry, Atan et al. [104] demonstrated that workers exposed to high temperatures, in whom low urine volumes and low urate citrate were observed, showed a 9-fold higher risk of urolithiasis. A tendency towards the incidence of kidney stones was also observed in marathon runners $[105,106]$. In an attempt to explain the results of these studies, it can be pointed out that relatively high temperatures can lead to dehydration, and that such conditions, with reduced or limited access to drinking water, become a source of exposure to people. In addition, during work under longterm exposure to the sun, the production of vitamin $\mathrm{D}_{3}$ increases and, after conversion to 1,25-dihydroxy-vitamin $\mathrm{D}_{3}$ in the kidneys, it may promote calcium absorption in the intestines, which also determines the development of the disease [107]. In general, the risk of developing urolithiasis in people working outdoors or exposed to high temperatures, e.g., steel workers, construction workers, road workers, farmers, miners, cooks, or drivers, are more susceptible to developing urolithiasis than people working at room temperature [74,108-110]. Despite this fact, some researchers in the above-mentioned field did not find a relationship; e.g., Iguchi et al. [111] noted that the administrative staff without exposure to high ambient temperatures were characterized by a higher incidence of kidney stones than farmers and workers with such exposure. In other studies, this inverse relationship was confirmed, consisting in a higher incidence of urolithiasis in people working indoors, especially office workers [109,112,113]. In search of the causes of this phenomenon, one may speculate that such people (leading a sedentary lifestyle) have an unhealthy lifestyle associated with, e.g., inappropriate dietary habits combined with the lack of physical activity and a relatively low intake of fluids.

Regarding the type of work (sitting, standing, exertional), Mates [114], in his research conducted in the Mariánské Lázně Spa (currently the second largest health resort in the Czech Republic), showed that among patients with health problems related to urolithiasis, office workers $(23 \%)$ and other workers performing sedentary work $(24 \%)$ were prevalent, while other groups were general physical workers $(16 \%)$, employees in transport services $(9 \%)$, housewives $(8 \%)$, pensioners $(5 \%)$, teachers $(5 \%)$, nurses and nursing assistants (4\%), and farmers (1\%). Subsequent works also confirmed an increased incidence of urolithiasis among persons engaged in a sedentary type of work [100]. 
The latest research reports by Hire et al. [115] showed that urolithiasis occurred more frequently in sedentary people $(67 \%)$ than in manual workers $(29 \%)$. Nagapurkar et al. [116] showed that among 104 Indian patients with symptoms of renal colic, occupational activity concerned a significant proportion of people working physically (physical work $-40.3 \%$, work in agriculture $29.80 \%$, work in the household - $11.5 \%$, students $10.5 \%$, others $-5.76 \%$ ). Achila et al. [117] noted that among 154 patients with deposits, 34\% were physical workers, and $29 \%$ office workers; the remaining percentage were unemployed or not professionally active. It should be mentioned that this research was conducted in Eritrea, located in East Africa. Due to these studies, other factors that accompany the development of urolithiasis should be taken into account.

According to Kalaitzidis et al. [118], doctors and medical personnel are among those professional groups that have a predisposition to the development of urolithiasis, which was noted already in the 1960s, and again in the 1980s [119,120]. In one of the latest studies in the USA (Mayo Clinic, Rochester, Minnesota), Linder et al. [121] showed that health workers working in operating rooms, especially doctors, were more exposed to urolithiasis. This study includes information on the potential risk factors such as the amount of daily fluid intake, stress level, activity level, BMI, appropriate medical conditions and family history of urolithiasis. The results confirmed that people working in operating rooms showed a higher incidence of the disease compared to people who worked in other hospital wards (14.6\% [64/439] vs. 9.7\% [132/1363]). Among physicians working in operating rooms, a significantly lower intake of fluids and higher levels of stress were observed, compared to employees not working in operating rooms.

Exposure factors may also include chemicals in the work environment [122,123]. Laerum and Aarseth [96] reported a causal relationship between the occurrence of urolithia- sis (53.3\%) among employees of Norwegian railway workshops and their exposure to oxalic acid used in the process of painting and cleaning railway wagons; according to earlier information, the excretion of oxalic acid in the urine is one of the main factors determining the formation of urinary stones. In other studies, there was a relationship between the formation of urolithiasis and exposure to selected chemical elements [124]. In the case of professions where work is performed in the manufacturing industry, and where there is a large exposure to harmful substances, the risk of urolithiasis is high. An example can be battery production industry workers who are exposed to high levels of cadmium $[125,126]$.

\section{CONCLUSIONS}

Currently, the presence of urolithiasis is becoming a significant problem all over the world. Therefore, it is necessary to monitor the spread of this adverse phenomenon in each country. The genesis of this disease is conditioned by many factors, so searching for causes is not easy, but particular attention should be paid to certain predispositions resulting from environmental factors such as ambient temperature and the type of work.

According to the analysis of collected literature data, one of the most important factors affecting the risk of urolithiasis is exposure to high ambient temperatures that is related to the warming of the climate, as well as the type of work performed. The external environment in which high temperatures are recorded can contribute to dehydration, and such conditions, with reduced or limited access to drinking water, become a source of exposure to people. In addition, during work under long-term exposure to the sun, the production of vitamin $\mathrm{D}_{3}$ increases and, after conversion to 1,25-dihydroxy-vitamin $\mathrm{D}_{3}$ in the kidneys, it may promote calcium absorption in the intestines, which also determines the development of the disease. Therefore, one of the solutions to the problem is to undertake health education and prevention in this area. 


\section{REFERENCES}

1. World Health Organization. International Statistical Classification of Diseases and Related Health Problems. ICD-10. Volume I. The Organization; 2009.

2. Tefekli A, Cezayirli F. The history of urinary stones: in parallel with civilization. Sci World J. 2013;2013:1-5, https://doi. org/10.1155/2013/423964.

3. Vijaya T, Sathish Kumar M, Ramarao NV, Naredra Babu A, Ramarao N. Urolithiasis and Its Causes-Short Review. J Phytopharmacol. 2013;2(3):1-6.

4. Świniarski PP. [Kidney stones - types, symptoms, treatment]. Przegl Urol. 2014;2(84):13-9. Polish.

5. Lallas CD, Liu XS, Chiura AN, Das AK, Bagley DH. Urolithiasis location and size and the association with microhematuria and stone-related symptoms. J Endourol. 2011;25(12):1909-13, https://doi.org/10.1089/end.2011.0265.

6. Durgawale P, Shariff A, Hendre A, Patil S, Sontakke A. Chemical analysis of stones and its significance in urolithiasis. Biomed Res. 2010;21(3):305-10.

7. Türk C, Knoll T, Petrik A, Sarica K, Skolarikos A, Straub M, et al., editors. EAU Guidelines on Urolithiasis [Internet]. European Association of Urology; 2016 [cited 2019 Apr 14]. Available from: https://uroweb.org/wp-content/uploads/ EAU-Guidelines-Urolithiasis-2016-1.pdf.

8. Zawadzki J, Imiela J. [Metabolic predisposition to the occurrence of nephrolithiasis]. Nowa Klin. 2000;7(5):525-8. Polish.

9. Swatowski A, Książek P. [Urolithiasis]. In: Książek A, Rutkowski B, editors. [Nephrology]. Lublin: 2004. p. 475. Polish.

10. Wrobel A, Rokita E, Taton G, Thor P. Chemical composition and morphology of renal stones. Folia Med Cracov. 2013;53(3):5-15.

11. Trinchieri A, Cappoli S, Esposito N, Acquati P. Epidemiology of renal colic in a district general hospital. Arch Ital Urol Androl. 2008;80(1):1-4, https://doi.org/10.1016/j.acpain.2008.05.015.

12. Brenner B, Rector JRF. Nephrolithiasis. In: Brenner BM, editor. Brenner and Rector's The Kidney. 8th ed. Philadelphia: 2008. p. 1299-49.
13. Curhan GC. Epidemiology of stone disease. Urol Clin North Am. 2007;3(3):287-93, https://doi.org/10.1016/j.ucl. 2007.04.003.

14. Ramello A, Vitale C, Marangella M. Epidemiology of nephrolithiasis. J Nephrol. 2000;13 Suppl 3:S45-50.

15. Vasudevan V, Samson P, Smith AD, Okeke Z. The genetic framework for development of nephrolithiasis. Asian J Urol. 2016;4(1):18-26, https://doi.org/10.1016/j.ajur.2016.11.003.

16. Halbritter J, Baum M, Hynes AM, Rice SJ, Thwaites DT, Gucev ZS, et al. Fourteen monogenic genes account for $15 \%$ of nephrolithiasis/nephrocalcinosis. J Am Soc Nephrol. 2015;26(3):543-51, https://doi.org/10.1681/ASN. 2014040388.

17. Halbritter J, Seidel A, Müller L, Schönauer R, Hoppe B. Update on Hereditary Kidney Stone Disease and Introduction of a New Clinical Patient Registry in Germany. Front Pediatr. 2018;6:47, https://doi.org/10.3389/fped.2018.00047.

18. Ganesamoni R, Singh SK. Epidemiology of stone disease in northern India. In: Talati J, Tiselius HG, Albala DM, YE Z, editors. Urolithiasis: basic science and clinical practice, vol 1: epidemiology. London: Springer; 2012. p. 39-46.

19. Tae BS, Balpukov U, Cho SY, Jeong CW. Eleven-year cumulative incidence and estimated lifetime prevalence of urolithiasis in Korea: a national health insurance service-national sample cohort based study. J Korean Med Sci. 2018;33:e13, https://doi.org/10.3346/jkms.2018.33.e13.

20. Liu Y, Chen Y, Liao B, Luo D, Wang K, Li H, et al. Epidemiology of urolithiasis in Asia. Asian J Urol. 2018;5(4):205-14, https://doi.org/10.1016/j.ajur.2018.08.007.

21. Ferrari P, Piazza R, Ghidini N, Bisi M, Galizia G, Ferrari G. Lithiasis and risk factors. Urol Int. 2007;79 Suppl 1:8-15, https://doi.org/10.1159/000104435.

22. Cook J, Lamb BW, Lettin JE, Graham SJ. The Epidemiology of Urolithiasis in an Ethnically Diverse Population Living in The Same Area. Urol J. 2016;13(4):2754-8.

23. Bartoletti R, Cai T, Mondaini N, Melone F, Travaglini F, Carini M, et al. Epidemiology and risk factors in urolithiasis. Urol Int. 2007;79 Suppl 1:3-7, https://doi.org/10.1159/000104434. 
24. López M, Hoppe B. History, epidemiology and regional diversities of urolithiasis. Pediatr Nephrol. 2010;25(1):49-59, https://doi.org/10.1007/s00467-008-0960-5.

25. Trinchieri A. Epidemiology of urolithiasis: an update. Clin Cases Miner Bone Metab. 2008;5(2):101-6.

26. Choi SY, Lee SY, Chi BH, Kim JW, Kim TH, Chang IH. Urbanization may affect the incidence of urolithiasis in South Korea. Springerplus. 2016;5(1):1891, https://doi.org/10.1186/ s40064-016-3554-x.

27. Pinduli I, Spivacow R, del Valle E, Vidal S, Negri AL, Previgliano $\mathrm{H}$, et al. Prevalence of urolithiasis in the autonomous city of Buenos Aires, Argentina. Urol Res. 2006;34(1):8-11, https://doi.org/10.1007/s00240-005-0003-7.

28. Stamatelou KK, Francis ME, Jones CA, Nyberg LM, Curhan GC. Time trends in reported prevalence of kidney stones in the United States: 1976-1994. Kidney Int. 2003;63(5): 1817-23, https://doi.org/10.1046/j.1523-1755.2003.00917.x.

29. Wang W, Fan J, Huang G, Li J, Zhu X, Tian Y, et al. Prevalence of kidney stones in mainland China: A systematic review. Sci Rep. 2017;7:41630, https://doi.org/10.1038/ srep41630.

30. Sas DJ, Hulsey TC, Shatat IF, Orak JK. Increasing incidence of kidney stones in children evaluated in the emergency department. J Pediatr. 2010;157(1):132-7, https://doi. org/10.1016/j.jpeds.2010.02.004.

31. Thomas BG. Management of stones in childhood. Curr Opin Urol. 2010;20(2):159-62, https://doi.org/10.1097/MOU.0b01 $3 \mathrm{e} 3283353 \mathrm{~b} 80$.

32. Sepahi MA, Heidari A, Shajari A. Clinical manifestations and etiology of renal stones in children less than 14 years age. Saudi J Kidney Dis Transpl. 2010;21(1):181-4.

33. Clayton DB, Pope JC. The increasing pediatric stone disease problem. Ther Adv Urol. 2011;3(1):3-12, https://doi. org/10.1177/1756287211400491.

34. Jobs K, Rakowska M, Paturej A. Urolithiasis in the pediatric population - current opinion on epidemiology, patophysiology, diagnostic evaluation and treatment. Dev Period Med. 2018;22(2):201-8.
35. Sas DJ. An update on the changing epidemiology and metabolic risk factors in pediatric kidney stone disease. Clin J Am Soc Nephrol. 2011;6(8):2062-8, https://doi.org/10.2215/ CJN.11191210.

36. Dwyer ME, Krambeck AE, Bergstralh EJ, Milliner DS, Lieske JC, Rule AD. Temporal trends in incidence of kidney stones among children: a 25-year population based study. J Urol. 2012;188(1):247-52, https://doi.org/10.1016/ j.juro.2012.03.021.

37. Sarica K, Eryildirim B, Yencilek F, Kuyumcuoglu U. Role of overweight status on stone-forming risk factors in children: a prospective study. Urology. 2009;73(5):1003-7, https://doi. org/10.1016/j.urology.2008.11.038.

38. Modi PK, Kwon YS, Davis RB, Elsamra SE, Dombrovskiy V, Olweny EO. Pediatric hospitalizations for upper urinary tract calculi: Epidemiological and treatment trends in the United States, 2001-2014. J Pediatr Urol. 2018;14(1):13. e1-6, https://doi.org/10.1016/j.jpurol.2017.09.001.

39. Bochniewska V, Jung A, Lichosik M. [Current problems of urolithiasis in children]. Pediatr Med Rodz. 2010;6(4):298303. Polish.

40. Kiliś-Pstrusińska K, Zwolińska D, Medyńska A. [Urolithiasis up to 4 years old]. Pol Merkur Lekarski. 2000;46:184-6. Polish.

41. Gołąbek B, Słowik M. Grabowska M, Kowalska B, Nowakowska K, Nowaczewska I. [Etiology of recurrent urolithiasis in children]. Med Wieku Rozwoj. 1998;1:71-85. Polish.

42. Kamińska A, Bieroza I. [Urolithiasis in children]. Borgis Nowa Pediatr. 2011;2:42-8. Polish.

43. Alelign T, Petros B. Kidney Stone Disease: An Update on Current Concepts. Adv Urol. 2018;2018:3068365, https://doi. org/10.1155/2018/3068365.

44. Singh KB, Sailo S. Understanding epidemiology and etiologic factors of urolithiasis: an overview. Scientific Visualization. 2013;13(4):169-74.

45. Sofia NH, Walter TM. Prevalence and risk factors of kidney stone. Glob J Res Anal. 2016;5(3):183-7.

46. Hesse A, Brändle E, Wilbert D, Köhrmann KU, Alken P. Study on the prevalence and incidence of urolithiasis in 
Germany comparing the years 1979 vs. 2000. Eur Urol. 2003;44(6):709-13, https://doi.org/10.1016/S0302-2838(03)004 15-9.

47. Ni Raghallaigh H, Ellis D, Symes A. Geographical and prevalence trends in urolithiasis in England: A ten-year review. Eur Urol Suppl. 2017;16(3);e1-2, https://doi.org/10.1016/ S1569-9056(17)30069-6.

48. Scales CD Jr, Smith AC, Hanley JM, Saigal CS, Urologic Diseases in America Project. Prevalence of kidney stones in the United States. Eur Urol. 2012;62(1):160-5, https://doi. org/10.1016/j.eururo.2012.03.052.

49. Raheem OA, Khandwala YS, Sur RL, Ghani KR, Denstedt JD. Burden of Urolithiasis: Trends in Prevalence, Treatments, and Costs. Eur Urol Focus. 2017;3(1):18-26, https:// doi.org/10.1016/j.euf.2017.04.001.

50. Nabi G, Downey P, Keeley F, Watson G, McClinton S. Extra-corporeal shock wave lithotripsy (ESWL) versus ureteroscopic management for ureteric calculi. Cochrane Database Syst Rev. 2007;(1):CD006029, https://doi. org/10.1002/14651858.CD006029.pub2.

51. Jayaraman UCh, Gurusamy A. Review on Uro-Lithiasis Pathophysiology and Aesculapian Discussion. IOSR J Pharm. 2018;8(2):30-42.

52. Roslan M, Zachalski W, Bagińska J, Krajka K. [Treatment methods for the treatment of urolithiasis]. For Nefrol. 2009;2(3):196-201. Polish.

53. Kretowicz M, Manitius J. [Nephrolithiasis and arterial hypertension]. Nadciśn Tętn. 2005;9:327-34. Polish.

54. Osther PJS. Epidemiology of Kidney Stones in the European Union. In: Talati J, Tiselius HG, Albala D, Ye Z. editors. Urolithiasis. London: Springer; 2012. p. 3-12, https:/doi. org/10.1007/978-1-4471-4387-1_1.

55. Worcester EM, Coe FL. Clinical practice. Calcium kidney stones. N Engl J Med. 2010;363(10):954-63, https://doi. org/10.1056/NEJMcp1001011.

56. Stąpor K. [Theories formation of urinary calculi] In: Leńko J, editor. [Urolithiasis]. Warszawa: PZWL; 1976. p. 24-30. Polish.
57. Basavaraj DR, Biyani CS, Browning AJ, Cartledge JJ. The role of urinary kidney stone inhibitors and promoters in the pathogenesis of calcium containing renal stones. EAU-EBU Update Series. 2007;5(3):126-36, https://doi.org/10.1016/ j.eeus.2007.03.002.

58. Bird VY, Khan SR. How do stones form? Is unification of theories on stone formation possible? Arch Esp Urol. 2017;70(1):12-27.

59. Duława J. [Factors of development of kidney stones]. For Nefrol 2009;2(3)184-8. Polish.

60. Gambaro G, Fabris A, Puliatta D. Lithiasis in cystic kidney disease and malformations of the urinary tract. Urol Res. 2006;34:102-7, https://doi.org/10.1007/s00240-005-0019-z.

61. Borg M, Bi P, Nitschke M, Williams S, McDonald S. The impact of daily temperature on renal disease incidence: an ecological study. Environ Health. 2017;16(1):114, https:// doi.org/10.1186/s12940-017-0331-4.

62. Goldfarb DS. The exposome for kidney stones. Urolithiasis. 2015;44(1):3-7, https://doi.org/10.1007/s00240-015-0847-4.

63. Fakheri RJ, Goldfarb DS. Ambient temperature as a contributor to kidney stone formation: implications of global warming. Kidney Int. 2011;79(11):1178-85, https://doi.org/ 10.1038/ki.2011.76.

64. Brikowski TH, Lotan Y, Pearle MS. Climate-related increase in the prevalence of urolithiasis in the United States. Proc Natl Acad Sci USA. 2008;105(28):9841-6, https://doi. org/10.1073/pnas.0709652105.

65. Soucie JM, Thun MJ, Coates RJ, McClellan W, Austin H. Demographic and geographic variability of kidney stones in the United States. Kidney Int. 1994;46(3):893-9.

66. Soucie JM, Coates RJ, McClellan W, Austin H, Thun M. Relation between geographic variability in kidney stones prevalence and risk factors for stones. Am J Epidemiol. 1996;143(5):487-95.

67. Bartoletti R, Cai T, Mondaini N, Melone F, Travaglini F, Carini $\mathrm{M}$, et al. Epidemiology and risk factors in urolithiasis. Urol Int. 2007;79 Suppl 1:3-7, https://doi.org/10.1159/0001 04434. 
68. Frank M, Atsmon A, Sugar P, De Vries A. Epidemiological investigation of urolithiasis in the hot arid Southern region of Israel. Urol Int. 1963;15:65-76, https://doi.org/ $10.1159 / 000279001$.

69. Chauhan V, Eskin B, Allegra JR, Cochrane DG. Effect of season, age, and gender on renal colic incidence. Am J Emerg Med. 2004;22(7):560-3, https://doi.org/10.1016/j.ajem. 2004.08.016.

70. Chen YK, Lin HC, Chen CS, Yeh SD. Seasonal variations in urinary calculi attacks and their association with climate: a population based study. J Urol. 2008;179(2):564-9, https:// doi.org/10.1016/j.juro.2007.09.067.

71. Fletcher BA, Lin S, Fitzgerald EF, Hwang SA. Association of summer temperatures with hospital admissions for renal diseases in New York State: a case-crossover study. Am J Epidemiol. 2012;175(9):907-16, https://doi.org/10.1093/ aje/kwr417.

72. Boyce CJ, Garver FK, Strawcutter HE. Incidence of urinary calculi among patients in general hospitals, 1948 to 1952. J Am Med Assoc. 1956;161(15):1437-42, https://doi. org/10.1001/jama.1956.02970150005002.

73. Tasian GE, Pulido JE, Gasparrini A, Saigal CS, Horton BP, Landis JR, et al. Daily mean temperature and clinical kidney stone presentation in five US metropolitan areas: a time-series analysis. Environ Health Perspect. 2014;122(10):1081-7, https://doi.org/10.1289/ehp.1307703.

74. Safarinejad MR. Adult urolithiasis in a population-based study in Iran: prevalence, incidence, and associated risk factors. Urol Res. 2007;35(2):73-82, https://doi.org/10.1007/ s00240-007-0084-6.

75. Alkhunaizi AM. Urinary stones in Eastern Saudi Arabia. Urol Ann. 2016;8(1):6-9, https://doi.org/10.4103/0974-7796. 164841.

76. Park HK, Bae SR, Kim SE, Choi WS, Paick SH, Ho K, et al. The effect of climate variability on urinary stone attacks: increased incidence associated with temperature over $18^{\circ} \mathrm{C}$ : a population-based study. Urolithiasis. 2015;43(1):89-94, https://doi.org/10.1007/s00240-014-0741-5.
77. Lee YH, Huang WC, Tsai JY, Lu CM, Chen WC, Lee MH, et al. Epidemiological studies on the prevalence of upper urinary calculi in Taiwan. Urol Int. 2002;68(3):172-7, https:// doi.org/10.1159/000048445.

78. Akinci M, Esen T, Tellaloğlu S. Urinary stone disease in Turkey: an updated epidemiological study. Eur Urol. 1991;20(3):200-3, https://doi.org/10.1159/000471700.

79. Barker DJ, Donnan SP. Regional variations in the incidence of upper urinary tract stones in England and Wales. $\mathrm{Br}$ Med J. 1978;1(6105):67-70.

80. Power C, Barker DJ, Blacklock NJ. Incidence of renal stones in 18 British towns. A collaborative study. Br J Urol. 1987;59(2):105-10, https://doi.org/10.1111/j.1464-410X.1987. tb04798.x.

81. Boscolo-Berto R, Dal Moro F, Abate A, Arandjelovic G, Tosato F, Bassi P. Do weather conditions influence the onset of renal colic? A novel approach to analysis. Urol Int. 2008;80(1):19-25, https://doi.org/10.1159/000111724.

82. Sirohi M, Katz BF, Moreira DM, Dinlenc C. Monthly variations in urolithiasis presentations and their association with meteorologic factors in New York City. J Endourol. 2014;28(5):599-604, https://doi.org/10.1089/end.2013.0680.

83. Stuart RO 2nd, Hill K, Poindexter J, Pak CY. Seasonal variations in urinary risk factors among patients with nephrolithiasis. J Lithotr Stone Dis. 1991;3(1):18-27.

84. Basiri A, Moghaddam SM, Khoddam R, Nejad ST, Hakimi A. Monthly variations of urinary stone colic in Iran and its relationship to the fasting month of Ramadan. J Pak Med Assoc. 2004;54(1):6-8.

85. Sagy I, Zeldetz V, Halperin D, Abu Tailakh M, Novack V. The effect of Ramadan fast on the incidence of renal colic emergency department visits. QJM. 2017;110(9):571-6, https://doi.org/10.1093/qjmed/hcx079.

86. Tang J, Chonchol MB. Vitamin D and kidney stone disease. Curr Opin Nephrol Hypertens. 2013;22(4):383-9, https:// doi.org/10.1097/MNH.0b013e328360bbcd.

87. Barger-Lux MJ, Heaney RP. Effects of above average summer sun exposure on serum 25-hydroxyvitamin $\mathrm{D}$ and calcium 
absorption. J Clin Endocrinol Metab. 2002;87(11):4952-6, https://doi.org/10.1210/jc.2002-020636.

88. Attalla K, De S, Sarkissian C, Monga M. Seasonal variations in urinary calcium, volume, and vitamin D in kidney stone formers. Int Braz J Urol. 2018;44(5):947-51, https://doi.org/ 10.1590/S1677-5538.IBJU.2018.0095.

89. Eisner BH, Eisenberg ML, Stoller ML. Relationship between body mass index and quantitative 24-hour urine chemistries in patients with nephrolithiasis. Urology. 2010;75(6): 1289-93, https://doi.org/10.1016/j.urology.2009.09.024.

90. Lee SC, Kim YJ, Kim TH, Yun SJ, Lee NK, Kim WJ. Impact of obesity in patients with urolithiasis and its prognostic usefulness in stone recurrence. J Urol. 2008;179(2):570-4, https://doi.org/10.1016/j.juro.2007.09.040.

91. Najeeb Q, Masood I, Bhaskar N, Kaur H, Singh J, Pandey R, et al. Effect of BMI and urinary $\mathrm{pH}$ on urolithiasis and its composition. Saudi J Kidney Dis Transpl. 2013;24(1):60-6.

92. Taylor EN, Curhan GC. Body size and 24-hour urine composition. Am J Kidney Dis. 2006;48(6):905-15, https://doi. org/10.1053/j.ajkd.2006.09.004.

93. Siener R, Glatz S, Nicolay C, Hesse A. The role of overweight and obesity in calcium oxalate stone formation. Obes Res. 2004;12(1):106-13, https://doi.org/10.1038/oby.2004.14.

94. Saneei P, Salehi-Abargouei A, Esmaillzadeh A. Serum 25-hydroxy vitamin $D$ levels in relation to body mass index: a systematic review and meta-analysis. Obes Rev. 2013;14(5):393-404, https://doi.org/10.1111/obr.12016.

95. Konradsen S, Ag H, Lindberg F, Hexeberg S, Jorde R. Serum 1,25-dihydroxy vitamin $\mathrm{D}$ is inversely associated with body mass index. Eur J Nutr. 2008;47(2):87-91, https://doi. org/10.1007/s00394-008-0700-4.

96. Laerum E, Aarseth S. Urolithiasis in railroad shopmen in relation to oxalic acid exposure at work. Scand J Work Environ Health. 1985;11(2):97-100, https://doi.org/10.5271/ sjweh.2241.

97. Evans K, Costabile RA. Time to development of symptomatic urinary calculi in a high risk environment. J Urol. 2005;173(3): 858-61, https://doi.org/10.1097/01.ju.0000152578.07262.1c.
98. Doumerc N, Game X, Mouzin M, Sallusto F, Soulie M, Rischmann P, et al. Suggestion of a two-month delay between extreme temperatures and renal colic. J Urol. 2008;179(suppl):481, https://doi.org/10.1016/S0022-5347(08)61414-7.

99. Pierce LW, Bloom B. Observations on urolithiasis among American troops in a desert area. J Urol. 1945;54:466-70, https://doi.org/10.1016/S0022-5347(17)70099-7.

100. Blacklock NJ. The pattern of urolithiasis in the Royal Navy. J R Nav Med Serv. 1965;51(2):99-111.

101. Haiming L. A case-control study of ambient heat exposure and urolithiasis among outdoor workers in a shipbuilding company, Guangzhou, China. Masters by research thesis. Queensland University of Technology; 2012.

102. Mulyani R, Soemarko DS, Widyahening IS. Association between heat exposure and urolithiasis in workers. J Phys Conf Ser. 2018;1073042043:1-6, https://doi.org/ 10.1088/1742-6596/1073/4/042043.

103. Borghi L, Meschi T, Amato F, Novarini A, Romanelli A, Cigala F. Hot occupation and nephrolithiasis. J Urol. 1993;150(6): 1757-60, https://doi.org/10.1016/S0022-5347(17)35887-1.

104. Atan L, Andreoni C, Ortiz V, Silva EK, Pitta R, Atan F, et al. High kidney stone risk in men working in steel industry at hot temperatures. Urology. 2005;65(5):858-61, https:// doi.org/10.1016/j.urology.2004.11.048.

105. Irving RA, Noakes TD, Rodgers AL, Swartz L. Crystalluria in marathon runners. 1. Standard marathon-males. Urol Res. 1986;14(6):289-94.

106. Milvy P, Colt E, Thornton J. A high incidence of urolithiasis in male marathon runners. J Sports Med Phys Fitness. 1981;21(3):295-8.

107. Freeg MA, Sreedharan J, Muttappallymyalil J, Venkatramana M, Shaafie IA, Mathew E, et al. A retrospective study of the seasonal pattern of urolithiasis. Saudi J Kidney Dis Transpl. 2012;23(6):1232-7, https://doi.org/10.4103/1319-2442.103565.

108. Mass AY, Goldfarb DS, Shah O. Taxi cab syndrome: a review of the extensive genitourinary pathology experienced by taxi cab drivers and what we can do to help. Rev Urol. 2014;16(3):99-104. 
109. Yoshida O, Okada Y. Epidemiology of urolithiasis in Japan: a chronological and geographical study. Urol Int. 1990;45(2):104-11, https://doi.org/10.1159/000281680.

110. Tanthanuch M, Apiwatgaroon A, Pripatnanont C. Urinary tract calculi in southern Thailand. J Med Assoc Thai. 2005;88(1):80-5.

111. Iguchi M, Umekawa T, Katoh Y, Kohri K, Kurita T. Prevalence of urolithiasis in Kaizuka City, Japan. An epidemiologic study of urinary stones. Int J Urol. 1996;3(3):175-9, https://doi.org/10.1111/j.1442-2042.1996.tb00511.x.

112. Abdel-Halim RE, Al-Hadramy MS, Hussein M, Baghlaf AO, Sibaai AA, Noorwali AW, et al. The prevalence of urolithiasis in the western region of Saudi Arabia: a population study. In: Walker VR, Sutton RAL, Cameron ECB, Pak CYC, Robertson WG, editors. Urolithiasis. Boston, MA: Springer; 1989. p. 711-2, https://doi.org/10. 1007/978-1-4899-0873-5_218.

113. Basiri A, Shakhssalim N, Khoshdel AR, Ghahestani SM, Basiri $\mathrm{H}$. The demographic profile of urolithiasis in Iran: a nationwide epidemiologic study. Int Urol Nephrol. 2010;42(1): 119-26, https://doi.org/10.1007/s11255-009-9588-z.

114. Mates J. External factors in the genesis of urolithiasis. In: Hodgkinson A, Nordin BEC, editors. Renal Stone Research Symposium. London: Churchill; 1969. p. 59.

115. Hire P, Tomar SS, Kher K. Clinical Profile And Management Of Multiple Urolithiasis. Int J Adv Res Ideas Innov Technol. 2017;3(2):584-97.

116. Nagapurkar A, Ghodake D, Mehta N, Joshi AG. A study of clinico demographic profile of patients with renal colic at tertiary health care center. Med Int Med J. 2017;4(12):1026, https://doi.org/10.26611/1004122.

117. Achila O, Araya M, Simel LL, Nanduri L, Asmerom A, Kiflay A, et al. An assessment of kidney stone composition and risk factors: Matched case-control study at Orotta referral hospital in Asmara, Eritrea. Int J Adv Community Med. 2018;1(2):7-14.
118. Kalaitzidis RG, Damigos D, Siamopoulos KC. Environmental and stressful factors affecting the occurrence of kidney stones and the kidney colic. Int Urol Nephrol. 2014;46(9):1779-84, https://doi.org/10.1007/s11255-0140758-2.

119. Larsen JF, Philip J. Studies on the incidence of urolithiasis. Urol Int. 1962;13:53-64, https://doi.org/10.1159/000278940.

120. Bakkaloglu MA, Erkan I, Ozen HA, Remzi D. A study on the prevalence of urolithiasis among Turkish medical doctors. Turk J Pediatr. 1984;26(1-4):5-9.

121. Linder BJ, Rangel LJ, Krambeck AE. The effect of work location on urolithiasis in health care professionals. Urolithiasis. 2013;41(4):327-31, https://doi.org/10.1007/s00240013-0579-2.

122. Gromadzińska J, Wąsowicz W. Health risk in road transport workers. Part I. Occupational exposure to chemicals, biomarkers of effect. Int J Occup Med Environ Health. 2019;32(3): 267-80, https://doi.org/10.13075/ijomeh.1896.01343.

123. Kataria A, Trasande L, Trachtman H. The effects of environmental chemicals on renal function. Nat Rev Nephrol. 2015;11(10):610-25, https://doi.org/10.1038/nrneph. 2015.94.

124. Yen Y, Cheng B, Chan C, Lin C, Chen H. Heavy metal components in blood and urinary stones of urolithiasis patients. Biol Trace Elem Res. 2018;185(2):266-74, https:// doi.org/10.1007/s12011-018-1253-X.

125. Järup L, Elinder CG. Incidence of renal stones among cadmium exposed battery workers. Br J Ind Med. 1993;50: 598-602.

126. Guo ZL, Wang JY, Gong LL, Gan S, Gu CM, Wang SS. Association between cadmium exposure and urolithiasis risk: A systematic review and meta-analysis. Medicine (Baltimore). 2018;97(1):e9460, https://doi.org/10.1097/MD.00000 00000009460 .

This work is available in Open Access model and licensed under a Creative Commons Attribution-NonCommercial 3.0 Poland License - http://creativecommons.org/ licenses/by-nc/3.0/pl/deed.en. 